\section{Carotid artery rupture following radioiodine therapy for differentiated thyroid carcinoma}

\author{
Ruptura de carótida pós-iodoterapia em \\ carcinoma diferenciado de tireoide
}

Danilo da Silva Cunha' ', Maria Izilda Previato Simões', Dionísio

Nepomuceno Viviani', Domingos Boldrini (in memoriam) ${ }^{2}$, Euclides

Timóteo da Rocha' ', Sandra Regina Morini ${ }^{3}$, Sonia Marta Moriguchi'

\section{SUMMARY}

Introduction: Radioiodine therapy for patients with differentiated thyroid cancer aims at reducing tumor recurrence by eradicating residual macro- and microscopic foci. Side effects are generally rare, tenuous and transient, with little clinical significance. Objective:To report a rare case of differentiated thyroid carcinoma presenting a large expansive solid mass at the base of the skull, with invasion of the left masticatory muscle and adjacent subcutaneous tissue, and without invasion of the carotid space, which evolved to carotid artery rupture following radioiodine therapy. Discussion: Side effects are uncommon after radioiodine therapy and when present, have mild intensity. Serious adverse events are very rare, especially those arising from structures not directly invaded by metastatic tissue with radioiodine uptake, as occurred in this case. This occurrence serves to raise awareness of the need for increased care when using radioiodine therapy on high-avidity masses located close to important structures. Arq Bras Endocrinol Metab. 2011;55(6):419-25

\section{SUMÁRIO}

Introdução: lodoterapia em pacientes com carcinoma diferenciado da tireoide tem o objetivo de reduzir a recorrência tumoral erradicando focos residuais macro e microscópicos. Os efeitos colaterais, em geral, são raros, tênues e transitórios, com pouca repercussão clínica. Objetivo: Relatar um caso raro de carcinoma diferenciado da tireoide apresentando grande massa sólida expansiva na base do crânio, com invasão da musculatura mastigatória esquerda e do tecido subcutâneo adjacente, sem invasão do espaço carotídeo que evoluiu com ruptura de carótida pós-iodoterapia. Discussão: Os efeitos colaterais pós-iodoterapia são pouco frequentes e, quando presentes, de intensidade discreta. Os eventos adversos graves são muito raros, em especial, aqueles decorrentes de estruturas não invadidas diretamente pelo tecido metastático iodocaptante, como nesse caso, alertando também para a necessidade do aumento dos cuidados na terapia de grandes massas ávidas pelo radioiodo próximas às estruturas nobres. Arq Bras Endocrinol Metab. 2011;55(6):419-25
${ }^{1}$ Department Nuclear Medicine, Hospital de Câncer de Barretos, Barretos, SP, Brazil

${ }^{2}$ Department Head and Neck Surgery, Hospital de Câncer de Barretos, Barretos, SP, Brazil

${ }^{3}$ Department Pathologic Anatomy, Hospital de Câncer de Barretos, Barretos, SP, Brazil

\section{INTRODUCTION}

$\mathrm{T}$ he incidence of thyroid neoplasms ranges from 0.5 to 10 cases per 100,000 inhabitants $(1)$, corresponding to $1 \%$ of malignant neoplastic diseases $(2,3)$. Papillary and follicular types are called well-differentiated, and correspond to $94 \%$ of the cases (3), with predominance of the first type (80\%) over the second type $(20 \%)$ (4). Follicular carcinoma presents greater inci- dence in areas where goiter is endemic, and iodine deficiency is the main contributing factor for the occurrence of this tumor $(3,5-7)$. Other conditions such as dyshormonogenetic goiter, previous irradiation, Cowden disease, hereditary nonmedullary thyroid cancer syndrome and, rarely, adenomas, have also been described $(3,8)$.

Recent advances in molecular biology have improved the understanding of thyroid carcinoma pathogenesis. Papillary thyroid cancers usually carry mutations 
and rearrangements that activate mitogen-activated protein kinase (MAPK). Rearrangements of RET and NTRKl tyrosine kinases, which activate mutations of BRAF and RAS, are sequential components of MAPK activation (9). These rearrangements result in production of chimeric proteins named RET/PTC and TRK. In adults, close to $40 \%$ of sporadic papillary cancers have these rearrangements, and RET rearrangements are about three times more common. The incidence of RET rearrangements in papillary cancers is higher in children, involving up to $80 \%$ of the cases of children exposed to external $\mathrm{x}$-irradiation, and those exposed to the Chernobyl nuclear accident $(10,11)$. Papillary thyroid cancers in patients with familial adenomatous polyposis frequently show RET rearrangements. BRAF proteins are serine-threonine kinases that activate the RAF/MEK/MAPK signaling pathway. The T1799A mutation of the BRAF gene affects up to $69 \%$ of papillary thyroid cancers and may be associated with worse clinical prognosis. RAS mutations are found in follicular adenomas and have been reported in the follicular variant of papillary thyroid cancers (12-17).

Genetic aberrations of follicular thyroid cancer include translocations (t[2,3][q13;p25]) (18), which result in fusion of part of the DNA-binding segment of PAX8 gene and peroxisome proliferator-activated receptor gamma 1 (PPAR-gamma-1) gene. PAX8 is a thyroid transcription factor, and PPAR-gamma- 1 is a transcription factor that stimulates cell differentiation and inhibits cell growth. Overexpression of normal c-myc and c-fos genes, as well as mutations of $\mathrm{H}$-ras, $\mathrm{N}$-ras, and K-ras proto-oncogenes, is found in follicular adenomas, follicular cancers and, occasionally, papillary cancers $(19,20)$. Allelic losses in these genes are also frequent in follicular cancers (21). Hypermethylation of RASSFlA, a known tumor-suppressing gene, has been described in one study in 9 out of 12 cases of follicular thyroid cancer, $44 \%$ benign adenoma cases, and $20 \%$ papillary thyroid cancer cases, reflecting an early step of thyroid carcinogenesis $(22,23)$.

New oncogenic signaling pathway inhibitors, growth or apoptosis modulators, angiogenesis inhibitors, immunomodulators and gene therapies are being tested in clinical trials. Drugs such as doxorubicin and cisplatin are related to partial responses and considerable toxicity. Other study targets are paclitaxel, carboplatin, epirubicin, axitinib, motesanib and sorafenib $(23,24)$. With the advances in understanding pathological mechanisms of molecular and cellular differentia- ted thyroid carcinoma, new therapies are being studied. However, so far, standard treatments based on surgery, radioiodine and sometimes radiation therapy remain the most commonly used.

Differentiated thyroid carcinoma is considered to be a disease of indolent course that is generally curable. Tumor recurrence occurs in about $20 \%$ to $40 \%$ of the cases, and up to $5 \%$ of the cases present cell undifferentiation (25-27). The hematogenic route is the most common route of dissemination route of follicular cases (28). Distant metastases occur in $15 \%$ to $20 \%$ of the cases, and mostly involving the lungs and bones (3). Less commonly, metastases can occur in the kidneys (29) and suprarenal region (30). We did not find any descriptions in the literature regarding invasion of the masticator spaces and adjacent subcutaneous region.

Nuclear medicine has a close relationship with this disease, since it is involved in the diagnosis and, particularly, in the treatment of the disease. Radioiodine therapy for patients with differentiated thyroid carcinoma aims at reducing tumor recurrence by eradicating residual microscopic foci. Side effects are generally rare, tenuous and transient.

The purpose of this report was to present the case of a patient with an unusual manifestation of follicular thyroid carcinoma with extensive metastatic infiltration at the base of the skull, who showed carotid artery rupture after radioiodine therapy, a complication that had not been described in the literature so far.

\section{CASE REPORT}

MDPM, a 47-year-old white woman, presented swelling on the left side of her face for the past three years. It intensified over the past few months, with associated difficulty in swallowing and breathing. Physical examination showed a large tumor in the left half of the face, with bulging of the maxilla and palate (Figure 1). Fine-needle aspiration puncture on the left maxilla revealed the presence of thyroid tissue. Thus, the investigation was directed towards the thyroid gland. Biochemical assays showed decreased TSH levels $(0.04 \mathrm{mIU} / \mathrm{mL}$, vs. ref. 0.2 to $4.2 \mathrm{mIU} / \mathrm{mL}$ ) and normal free T4 levels $(0.81 \mathrm{ng} / \mathrm{dL}$, vs. ref. 0.71 to $1.85 \mathrm{ng} / \mathrm{dL})$ near to $\mathrm{lo}^{-}$ wer limit without clinical symptoms. Ultrasound examination demonstrated that the thyroid was eutopic, with enlarged, lobulated and at least three hyperechoic nodules in the gland (one with peripheral calcification around it, measuring $1.4 \mathrm{~cm}$ ). Fine-needle aspiration 
identified the presence of colloid goiter, and no lymph node enlargement or extrathyroid cervical extension. The same nodule measuring $1.4 \mathrm{~cm}$ was identified as a cold nodule in the middle third of the right lobe, using scintigraphy with ${ }^{99 \mathrm{~m}} \mathrm{Tc}$-pertechnetate. Computed tomography of the paranasal sinuses showed a large solid expansive mass measuring $8.0 \times 9.0 \times 11.7 \mathrm{~cm}$, affecting an extensive area at the base of the skull, invading the left masticatory muscles and adjacent subcutaneous tissue, but not invading the carotid spaces (Figure 2).

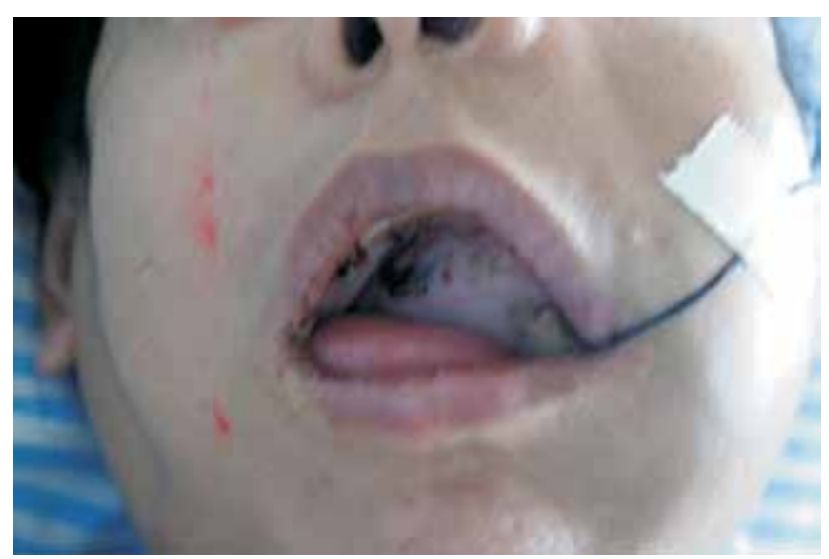

Figure 1. Tumor development on the left side of the face.

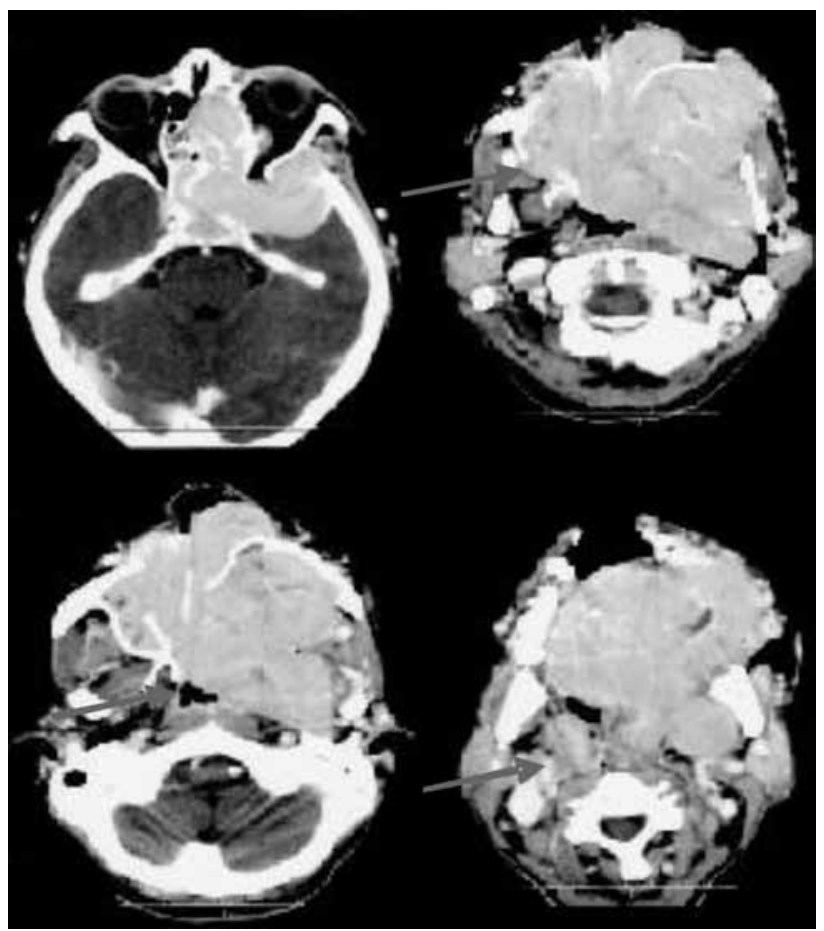

Figure 2. Computed tomography of paranasal sinuses, showing a large expansive lesion with its epicenter in the maxilla bone, affecting the maxillary sinuses, nasal cavity and palate, invading the base of the skull, compressing the brain parenchyma, and invading the masticatory space and subcutaneous tissue on the left side of the face.
A biopsy on the left maxilla detected metastasis of a well-differentiated follicular thyroid carcinoma, which was confirmed by immunohistochemical analysis (Figure 3 ). The patient then underwent total thyroidectomy, and the anatomopathological examination on the specimen confirmed the presence of follicular carcinoma in both lobes of the gland as previously mentioned (Figure 4).

In order to determine the complementary therapy, the patient underwent whole-body investigation scan ${ }^{131}$ I (Figure 5) and bone scintigraphy (Figure 6), which found bone and soft-tissue lesion with high radioiodine uptake taking almost the entire left side of the face. We decided to administer radioiodine therapy at a 9250 $\mathrm{MBq}(250 \mathrm{mCi})$ dose, which was done without any immediate intercurrences.

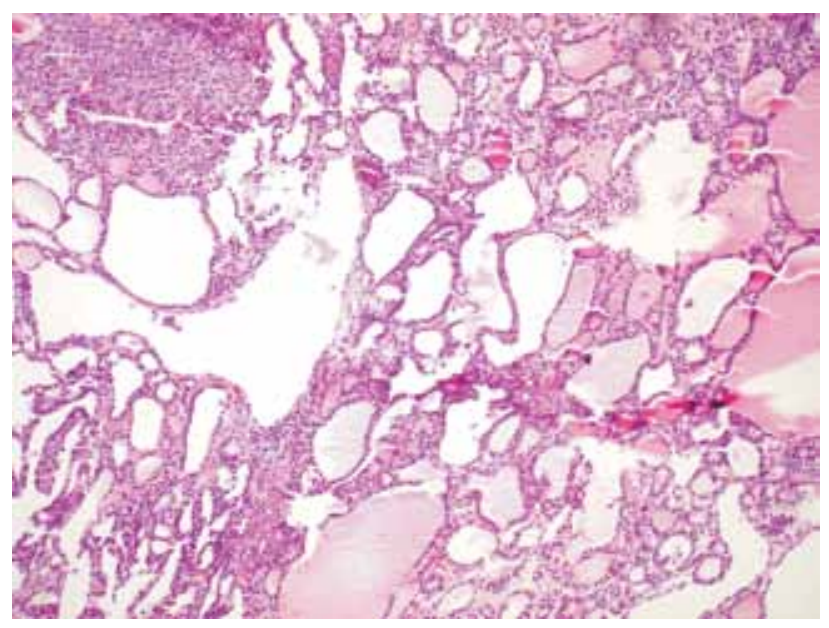

Figure 3. Photomicrograph of the left maxilla, showing infiltration by welldifferentiated follicular thyroid carcinoma.

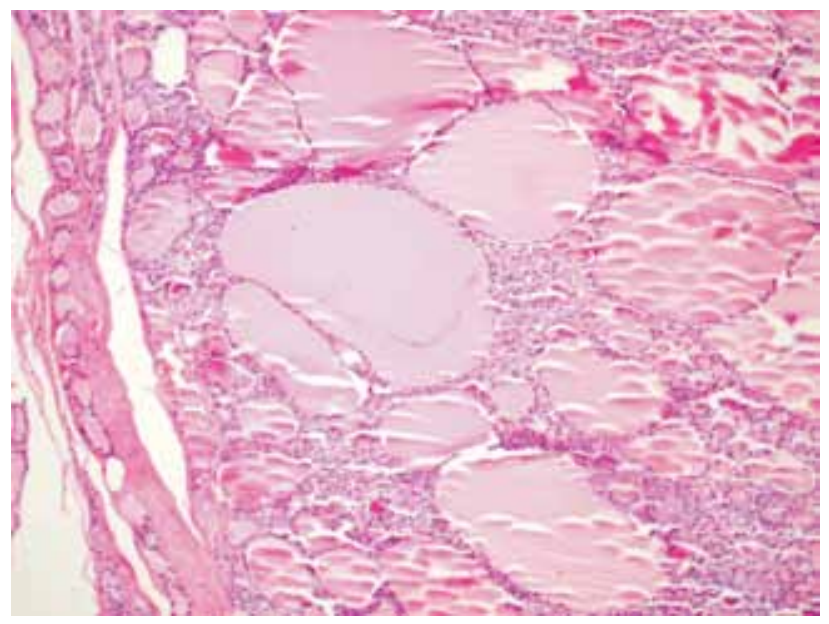

Figure 4. Photomicrograph of the thyroid gland, showing well-differentiated and encapsulated follicular carcinoma. 


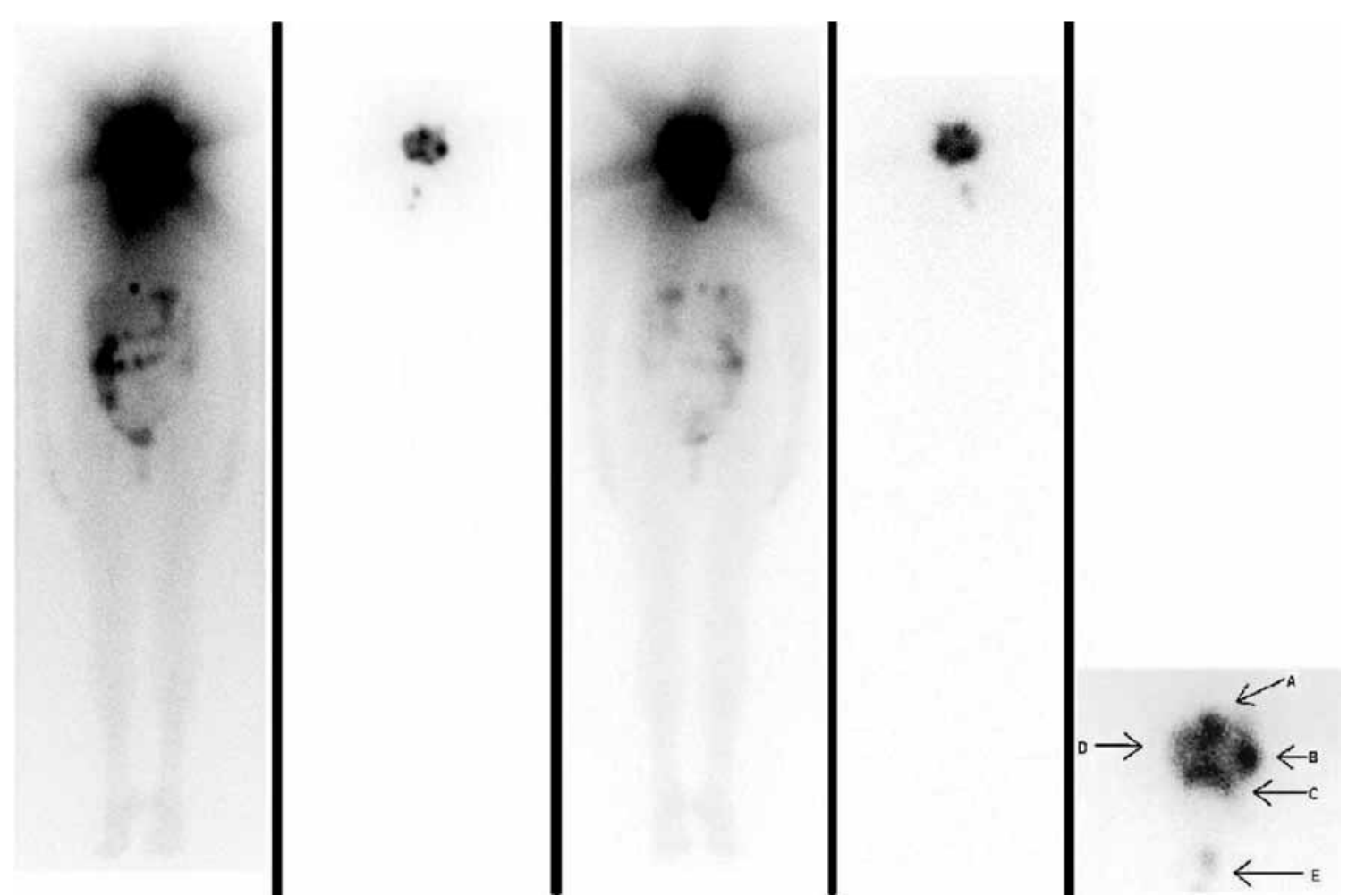

Figure 5. Whole-body scan using iodine 131 at diagnosis and after radioiodine therapy. A voluminous tumoral mass with iodine uptake is seen occupying the paranasal sinuses, nasal region and oral cavity, and extending to the base of the skull, with imprecise limits and swollen appearance. From left to right: anterior view after diagnosis and after therapy; posterior view after diagnosis and after therapy. Highlighted anatomical relationships: A: nose; B: left maxilla; C: mouth; D: right maxilla; E: remainder of the thyroid.

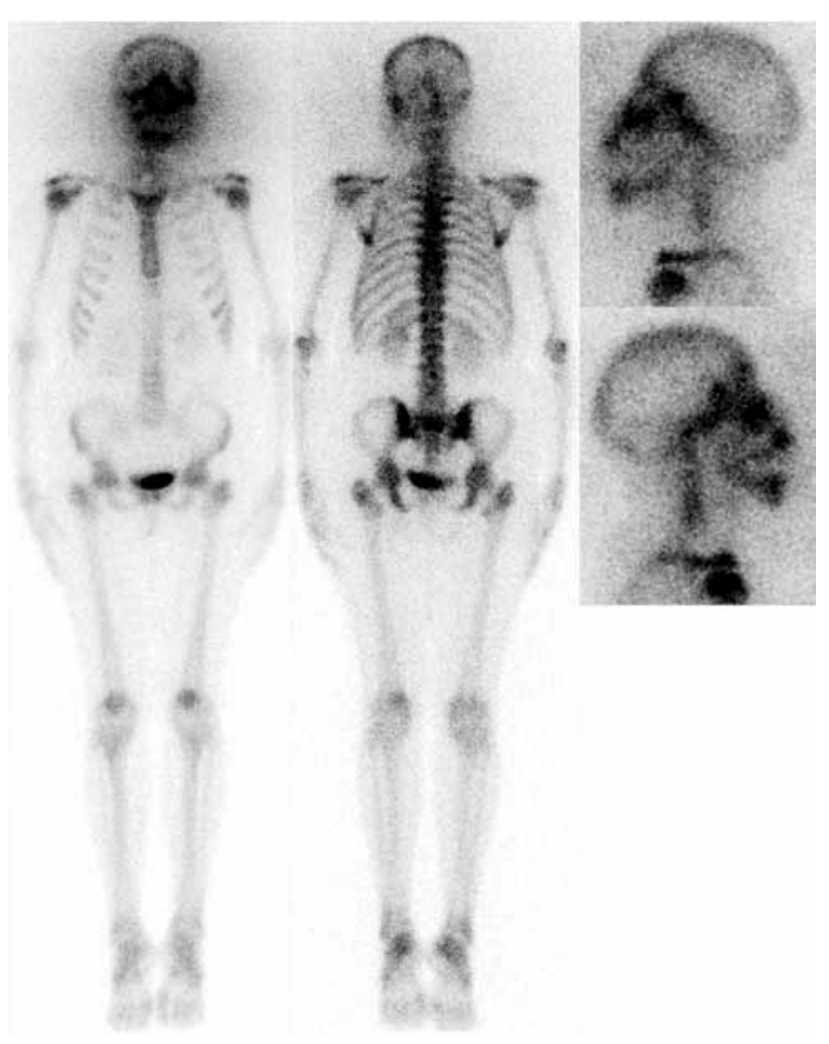

Figure 6. Bone scintigraphy performed using ${ }^{99 m} T C-M D P$, showing osteoblastic and osteolytic bone metastases on the left side of the face, with expansion into soft tissues.
Seventeen days after therapy, the patient complained of intense progressive pain on the left side of the face, associated with edema. This persisted for other five days and culminated in the rupture of the ipsilateral external carotid ( 22 days after the radioiodine therapy). An emergency procedure involving exploratory cervicotomy and ligature of the vessels was carried out. After stabilization, the patient was discharged from the hospital without bleeding or complaining of pain, and with decreased tumor volume.

\section{DISCUSSION}

Thyroid cancer accounts for less than $1 \%$ of all cancers, and malignant endocrine tumors are the most common type. They are more prevalent in women than in men $(3: 1)$, and occur most frequently at reproductive age (1). The vast majority, around 94\%, derives from follicular epithelial cells of the thyroid and are classified as differentiated, and are called either papillary or follicular. Another 5\% are medullary carcinomas of the thyroid. The remainder (1\%) are anaplastic tumors $(3,31)$. Upon physical examination, it is possible to find thyroid nodules in around $5 \%$ of female patients and $1 \%$ of male 
patients. Consequently, incidence of this carcinoma has been found to range from $5 \%$ to $15 \%$, depending on the age, sex, history of exposure to ionizing radiation, and any family history of thyroid cancer. Using high-resolution cervical ultrasonography, the rate of nodule findings ranges from $19 \%$ to $67 \%$, and is higher in female and elderly patients. Characteristics such as the presence of microcalcifications, hypoechoic nodules, increased vascularization, infiltrative margins and increased size are signs that lead to suspicion of carcinoma (24).

Lymph node involvement occurs in $20 \%$ to $50 \%$ of the cases, particularly in papillary carcinomas, and may even occur in cases of small intrathyroid primary tumors. Lymph node levels commonly affected are III, IV and VI. It is believed that while papillary thyroid carcinoma presents preferential dissemination by lymphatic route, hematogenic route is more common in the dissemination of follicular thyroid carcinoma. Lungs and bones are the most frequent sites for distant metastases, with rare reports of metastases in the kidneys and suprarenal area $(3,24,28-30)$. The sites of metastasis observed in the present case have never been described in the literature.

The approach used for differentiated thyroid carcinoma patients consists on the removal of the primary tumor, which decreases the morbidity related to the treatment and staging of the disease, and facilitates treatment with complementary radioiodine therapy. In differentiated thyroid carcinoma cases with metastatic lesions, there is a therapeutic sequence that needs to be followed. Surgery is the main intervention, followed by radioiodine therapy, external beam radiotherapy, and other attempts to alleviate the condition.

Chemical properties of ${ }^{131} \mathrm{I}$ are identical to those of stable iodine, and it has the same role in metabolic processes and thyroid hormone synthesis. The basis of radioiodine therapy is as follows: tissue ionization triggered by the emission of ${ }^{131} \mathrm{I}$ beta radiation destroys macromolecules as a consequence of either direct interaction with radiation or production of free radicals caused by breaking of water molecules. Irradiation may also activate cell apoptosis by means of three mechanis$\mathrm{ms}$. The first is the loss of the ligand/receptor system, thereby triggering the tumor necrosis factor family; the second involves members of the pro- and anti-apoptotic $\mathrm{Bcl} 2$ family; both of these converge towards the third mechanism, which involves caspase activation (32).

Therefore, the basis of radioiodine therapy is that it attempts to destroy the macroscopic thyroid tissue or the remaining microscopic cell tissue after surgical resection (4). Its use enables a correlation between increased serum thyroglobulin levels and tumor recurrence or growth, in that the remaining healthy thyroid tissue was destroyed by radioiodine therapy. The first dose of radioiodine therapy can be considered an adjuvant therapy for treating well-differentiated thyroid carcinoma.

This therapy is recommended for high and intermediate-risk patients and, to a limited extent, for low-risk patients $(24,33,34)$. In high-risk patients with macroscopic tumor invasion, incomplete tumor resection, distant metastases and disproportionate thyroglobulin levels, total thyroidectomy with surgical removal of all possible locoregional disease is an important step in the initial treatment, since it may lead to possible response of the metastases to radioiodine therapy (24). Because of the severe metastatic infiltration into several structures of our patient, removal of the metastases was impossible, and we decided to use complementary non-surgical radioiodine therapy, given that the mass would concentrate the radioisotope.

There is a current lack of prospective randomized studies that might enable standardization of the administration of iodine 13lactivity. Fixed empirical quantities are used, along with fixed blood assay levels and absorbed tumor doses. Minimum activity levels of 1110 $\mathrm{MBq}(30 \mathrm{mCi})$ to $3700 \mathrm{MBq}(100 \mathrm{mCi})$ have been described for low-risk patients. However, when an activity level of $1110 \mathrm{MBq}$ is used, a second therapeutic dose is necessary for ablation (35). Increasing quantities, going over $3700 \mathrm{MBq}$, according to the severity of the case and the potential therapeutic value of radioiodine, are recommended. For patients like ours, in whom radioiodine therapy interferes with the potential prolonged survival, empirical administration of 5550 $\mathrm{MBq}(150 \mathrm{mCi})$ to $11100 \mathrm{MBq}(300 \mathrm{mCi})$ is recommended, although it does not have curative potential $(1,24)$. We believe that the choice of an activity level of $9250 \mathrm{MBq}(250 \mathrm{mCi})$ in our case, without fractioning, brought the disease under control within a shorter time, with diminished respiratory symptoms.

Radioiodine therapy requires stimulation of TSH to values greater than $30 \mathrm{mU} / \mathrm{L}$. Elevation of endogenous TSH can be achieved by suspending levothyroxine use for four weeks in adults and for 14 days in children, together with an iodine-poor diet for around two weeks. Elevation of TSH can also be achieved by means of exogenous TSH, with recombinant human TSH (rhTSH). Use of rhTSH has been correlated with 
lower radioiodine uptake in therapeutic targets than in patients undergoing LT4 restriction and iodine-poor diet, thereby increasing the possibility of rapid expansion of metastatic lesions (24). Because of the presence of extensive functioning metastatic thyroid tissue with high avidity for radioiodine, there was no need to stimulate TSH for iodine therapy.

Mild adverse reactions have been described in radioiodine therapy, such as acute irradiation syndrome, pain, local edema, hypoparathyroidism, sialadenitis, xerostomy, changes in taste, gastritis, local pain at secondary implantation foci, and transient gonadal hypofunction. Acute reactions of greater severity include transient medullary depression, radiation pneumonitis, edema and bleeding at metastatic foci such as the lungs and brain. There are reports of such reactions leading to death $(1,32)$. Late-stage complications include chronic sialadenitis, lithiasis in the salivary glands, pulmonary fibrosis, acute myeloid leukemia, oligospermia or azoospermia (1).

Although adverse events following radioiodine therapy are uncommon and tenuous, they may signal complications of greater severity, particularly in regions close to large masses with high radioiodine uptake. Corticoid use has been recommended, especially in cases of extensive metastatic lung infiltrations, in an attempt to diminish the inflammatory process and the severity of fibrotic sequelae.

High iodine uptake in the present report was responsible for massive locoregional cell death, thereby triggering carotid rupture. This was been predicted from the course of the case, given that this occurrence has not been described in the literature, and tomography had not suggested that the metastasis might invade the blood vessel. It is possible that corticoid use would have benefited out patient, avoiding severe complications.

Radiotherapy was not recommended in our case, because of the high avidity of the metastatic mass for radioiodine which was achieved during the diagnostic whole-body scanning. Thus, therapy using radioiodine was preferred. This decision was also made because of the lack of prospective randomized studies describing the impact of external beam radiotherapy on survival (23,24,36-38). Nonetheless, the British Thyroid Association has recommended external beam radiotherapy for patients over 60 years of age with extensive extranodal spreading, after they have undergone optimized surgical therapy. Furthermore, the American Thyroid Association has suggested that it may be possible to use radiotherapy for patients over 45 years of age who, during the operation, show visible extrathyroid extension of the disease, and potential microscopic residual disease $(24,38)$. For tumors that invade the aerodigestive tract, external beam radiotherapy may also assist in controlling the disease, when associated with surgery and radioiodine therapy. Its use has also been described for lesions with a propensity to fracture, symptoms of compressive origin and bone pain.

In conclusion, although adverse events with severe clinical repercussions are rare among differentiated thyroid carcinoma patients after iodine therapy, special preventative care may be necessary. Preventative corticoid therapy and follow-up or hospitalization for two to three weeks may diminish the inflammatory reaction, and the time of peak tissue destruction may be observed by the medical team.

Disclosure: no potential conflict of interest relevant to this article was reported.

\section{REFERENCES}

1. Maia AL, Ward LS, Carvalho GA, Graf H, Maciel RM, Maciel LM, et al. [Thyroid nodules and differentiated thyroid cancer: Brazilian consensus]. Arq Bras Endocrinol Metabol. 2007;51(5):867-93.

2. Edwards BK, Howe HL, Ries LA, Thun MJ, Rosenberg HM, Yancik $\mathrm{R}$, et al. Annual report to the nation on the status of cancer, 19731999 , featuring implications of age and aging on U.S. cancer burden. Cancer. 2002;94(10):2766-92.

3. Golbert L, Wajner SM, Rocha AP, Maia AL, Gross JL. Differentiated thyroid carcinoma: initial evaluation and follow-up. Arq Bras Endocrinol Metabol. 2005;49(5):701-10.

4. Sawka AM, Thephamongkhol K, Brouwers M, Thabane L, Browman G, Gerstein HC. Clinical review 170: a systematic review and metaanalysis of the effectiveness of radioactive iodine remnant ablation for well-differentiated thyroid cancer. J Clin Endocrinol Metab. 2004;89(8):3668-76.

5. Mazzaferri EL. Papillary thyroid carcinoma: factors influencing prognosis and current therapy. Semin Oncol. 1987;14(3):315-32.

6. Medeiros-Neto A. Bócio endêmico, levantamento de sua prevalência em todo território brasileiro por microrregiões homogêneas. Rev Bras Mal DTrop. 1976;28:1-226.

7. Pacini F, Schlumberger MJ. Thyroid Tumors. 2nd ed. Paris: Editions Nucleons; 2003.

8. Ron E, Lubin JH, Shore RE, Mabuchi K, Modan B, Pottern LM, et al. Thyroid cancer after exposure to external radiation: a pooled analysis of seven studies. Radiat Res. 1995;141(3):259-77.

9. Kimura ET, Nikiforova MN, Zhu Z, Knauf JA, Nikiforov YE, Fagin JA. High prevalence of BRAF mutations in thyroid cancer: genetic evidence for constitutive activation of the RET/PTC-RAS-BRAF signaling pathway in papillary thyroid carcinoma. Cancer Res. 2003;63(7):1454-7.

10. Bongarzone I, Vigneri P, Mariani L, Collini P, Pilotti S, Pierotti MA. RET/NTRK1 rearrangements in thyroid gland tumors of the papillary carcinoma family: correlation with clinicopathological features. Clin Cancer Res. 1998;4(1):223-8. 
11. Nikiforov YE, Rowland JM, Bove KE, Monforte-Munoz H, Fagin JA. Distinct pattern of ret oncogene rearrangements in morphological variants of radiation-induced and sporadic thyroid papillary carcinomas in children. Cancer Res. 1997;57(9):1690-4.

12. Cohen $Y$, Xing M, Mambo E, Guo Z, Wu G, Trink B, et al. BRAF mutation in papillary thyroid carcinoma. J Natl Cancer Inst. 2003;95(8):625-7.

13. Kim J, Giuliano AE, Turner RR, Gaffney RE, Umetani N, Kitago M, et al. Lymphatic mapping establishes the role of BRAF gene mutation in papillary thyroid carcinoma. Ann Surg. 2006;244(5):799-804.

14. Kim TY, Kim WB, Rhee YS, Song JY, Kim JM, Gong G, et al. The BRAF mutation is useful for prediction of clinical recurrence in low-risk patients with conventional papillary thyroid carcinoma. Clin Endocrinol (Oxf). 2006;65(3):364-8.

15. Oler G, Ebina KN, Michaluart P Jr, Kimura ET, Cerutti J. Investigation of BRAF mutation in a series of papillary thyroid carcinoma and matched-lymph node metastasis reveals a new mutation in metastasis. Clin Endocrinol (Oxf). 2005;62(4):509-11.

16. Powell N, Jeremiah S, Morishita M, Dudley E, Bethel J, Bogdanova $T$, et al. Frequency of BRAF T1796A mutation in papillary thyroid carcinoma relates to age of patient at diagnosis and not to radiation exposure. J Pathol. 2005;205(5):558-64.

17. Salvatore G, Giannini R, Faviana $P$, Caleo A, Migliaccio I, Fagin JA, et al. Analysis of BRAF point mutation and RET/PTC rearrangement refines the fine-needle aspiration diagnosis of papillary thyroid carcinoma. J Clin Endocrinol Metab. 2004;89(10):5175-80.

18. Kroll TG, Sarraf P, Pecciarini L, Chen CJ, Mueller E, Spiegelman $\mathrm{BM}$, et al. PAX8-PPARgamma1 fusion oncogene in human thyroid carcinoma [corrected]. Science. 2000;289(5483):1357-60.

19. Karga H, Lee JK, Vickery AL Jr, Thor A, Gaz RD, Jameson JL. Ras oncogene mutations in benign and malignant thyroid neoplasms. J Clin Endocrinol Metab. 1991;73(4):832-6.

20. Marques AR, Espadinha $C$, Catarino AL, Moniz S, Pereira T, Sobrinho LG, et al. Expression of PAX8-PPAR gamma 1 rearrangements in both follicular thyroid carcinomas and adenomas. J Clin Endocrinol Metab. 2002;87(8):3947-52.

21. Ward LS, Brenta G, Medvedovic M, Fagin JA. Studies of allelic loss in thyroid tumors reveal major differences in chromosomal instability between papillary and follicular carcinomas. J Clin Endocrinol Metab. 1998;83(2):525-30.

22. Xing M, Cohen Y, Mambo E, Tallini G, Udelsman R, Ladenson PW, et al. Early occurrence of RASSF1A hypermethylation and its mutual exclusion with BRAF mutation in thyroid tumorigenesis. Cancer Res. 2004;64(5):1664-8.

23. Gasent Blesa JM, Grande Pulido E, Provencio Pulla M, Alberola Candel V, Laforga Canales JB, Grimalt Arrom M, et al. Old and new insights in the treatment of thyroid carcinoma. JThyroid Res. 2010:279468.
24. Cooper DS, Doherty GM, Haugen BR, Kloos RT, Lee SL, Mandel SJ, et al. Revised American Thyroid Association management guidelines for patients with thyroid nodules and differentiated thyroid cancer. Thyroid. 2009;19(11):1167-214.

25. Coelho SM, Carvalho DP, Vaisman M. New perspectives on the treatment of differentiated thyroid cancer. Arq Bras Endocrinol Metabol. 2007;51(4):612-24.

26. Mazzaferri EL, Massoll N. Management of papillary and follicular (differentiated) thyroid cancer: new paradigms using recombinant human thyrotropin. Endocr Relat Cancer. 2002;9(4):227-47.

27. Schlumberger MJ. Papillary and follicular thyroid carcinoma. N Engl J Med. 1998;338(5):297-306.

28. Clark $\mathrm{OH}$. Cirurgia diagnóstico e tratamento. 9th ed. Rio de Janeiro: Guanabara Koogan; 1993.

29. Cherk MH, Moore M, Serpell J, Swain S, Topliss DJ. Metastatic colorectal cancer to a primary thyroid cancer. World J Surg Oncol. 2008;6:122.

30. Garcia JCF, Torres JFM, Marco JLP, Sellés FP. Metastasis poco habituales del carcinoma diferenciado de tiroides. An Med Interna. 2002;19(11):579-82.

31. Sherman SI. Thyroid carcinoma. Lancet. 2003;361(9356):501-11.

32. Mathonnet $M$, Clavel M, Labrousse F, Chianéa T. Unusual fatal effect of radioiodine (I - 131) therapy: a case report. World $\mathrm{J}$ Nucl Med. 2009;8(3):187-91.

33. Hay ID, Hutchinson ME, Gonzalez-Losada T, Mclver B, Reinalda $\mathrm{ME}$, Grant CS, et al. Papillary thyroid microcarcinoma: a study of 900 cases observed in a 60-year period. Surgery. 2008;144(6):9807; discussion 7-8.

34. Ross DS, Litofsky D, Ain KB, Bigos T, Brierley JD, Cooper DS, et al. Recurrence after treatment of micropapillary thyroid cancer. Thyroid. 2009;19(10):1043-8.

35. Kukulska A, Krajewska J, Gawkowska-Suwinska M, Puch Z, Paliczka-Cieslik E, Roskosz J, et al. Radioiodine thyroid remnant ablation in patients with differentiated thyroid carcinoma (DTC): prospective comparison of long-term outcomes of treatment with 30 , 60 and $100 \mathrm{mCi}$. Thyroid Res. 2010;3(1):9.

36. Kim TH, Yang DS, Jung KY, Kim CY, Choi MS. Value of external irradiation for locally advanced papillary thyroid cancer. Int J Radiat Oncol Biol Phys. 2003;55(4):1006-12.

37. Tsang RW, Brierley JD, Simpson WJ, PanzarellaT, Gospodarowicz MK, Sutcliffe SB. The effects of surgery, radioiodine, and external radiation therapy on the clinical outcome of patients with differentiated thyroid carcinoma. Cancer. 1998;82(2):375-88.

38. Sia MA,Tsang RW, PanzarellaT, Brierley JD. Differentiated thyroid cancer with extrathyroidal extension: prognosis and the role of external beam radiotherapy. JThyroid Res. 2010:183461. 